\title{
Novel Techniques for Gene Delivery into Plants and Its Applications for Disease Resistance in Crops
}

\author{
Ahmad Hama Ameen Rashid, Djshwar Dhahir Lateef \\ Field Crop Departments, College of Agriculture, University of Sulaimani, Sulaimaniyah, Iraq \\ Email: ahmad.hamarashid@univsul.edu.iq, djshwar.lateef@univsul.edu.iq \\ Received 1 December 2015; accepted 25 January 2016; published 28 January 2016 \\ Copyright $@ 2016$ by authors and Scientific Research Publishing Inc. \\ This work is licensed under the Creative Commons Attribution International License (CC BY). \\ http://creativecommons.org/licenses/by/4.0/ \\ (c) (i) 0 pen Access
}

\begin{abstract}
From the early past to the present, biotechnologies have produced the ability to genetically transform a wide variety of plant species. The plant transformation technologies have changed the face of agriculture and plant biology. Plant genetic transformation is one of the key technologies for crop improvement in addition to emerging approach for producing recombinant proteins in plants. Both plastid genomes and plant nuclear can be genetically modified. Until now, essential functional differences between the prokaryotic-like genome of the plastid and the eukaryotic genome of the plant cell nucleus will have an impact on characteristics of transgenic organism. Thus, the main goals are to generate transgenic plants with the traits of interest as well as minimizing the amount of transgenic DNA in plants while maximizing stability of gene expression and trait performance. In this review, two broad groups of gene delivery methods will be discussed namely, (bilogical and physical methods) and subsequently there applications for improving disease resistance will be discussed.
\end{abstract}

\section{Keywords}

T-DNA, Particle Bombardment, MSNs, Silicon Carbide-Mediated Transformation, Electroporation

\section{Introduction}

Fundamental element for crop improvement and development of new cultivars with desirable characters is the ability to modify the genetic composition of a plant. To develop new lines by sexual hybridization, plant breeders have employed the naturally happening genetic variability in existing germplasm [1].

To generate genetic variability, the development of somatic cell hybridization and protoplast culture is one of 
the first patterns. Additionally, in vitro culture of plant cells in suboptimal conditions is established to induce genetic variations which term somaclonal variation [2]. To create genetic variation across species, the Agrobacterium tumefaciens-mediated integration of foreign DNA into a cell's nuclear genome has become the method of choice in which the introduced gene is inherited following Mendelian genetics, regardless of sexual compatibility or genetic proximity [3].

The first step for genetic transformation is the DNA delivery to cells or tissues, followed by culture and selection to permit only those tissues and cells having a marker gene (for instance, herbicide resistance gene or antibiotic) to proliferate and survive further. Then, plants are regenerated from the surviving cells, embedded and rooted in the soil. Such primary transformants after that are used for molecular analyses for determination of copy number of the transgenes of interest [4] [5] (For more details, see Figure 1).

Approaches for delivering DNA into plant cells and gene transformation can be divided into two major categories: direct and indirect DNA deliveries. Direct method does not employ bacterial cells as mediators, as an alternative, it uses a chemical alteration or physical force such as electric discharge or pressure to deliver the vector DNA into a host cell [5]. Whereas, in indirect approach, genes of interest are introduced into the target cell through bacteria, for instance, Agrobacterium tumefaciens or Agrobacterium rhizogenes [1]. For introducing genes into plants, microprojectile bombardment and Agrobacterium-mediated gene transfer direct are the most widely exploited methods because of their ability to transform intact, re-generable tissues and organs [6]-[8]. In this essay, two broad groups of gene delivery methods will be discussed namely (bilogical and physical methods), and subsequently there applications for improving disease resistance will be discussed.

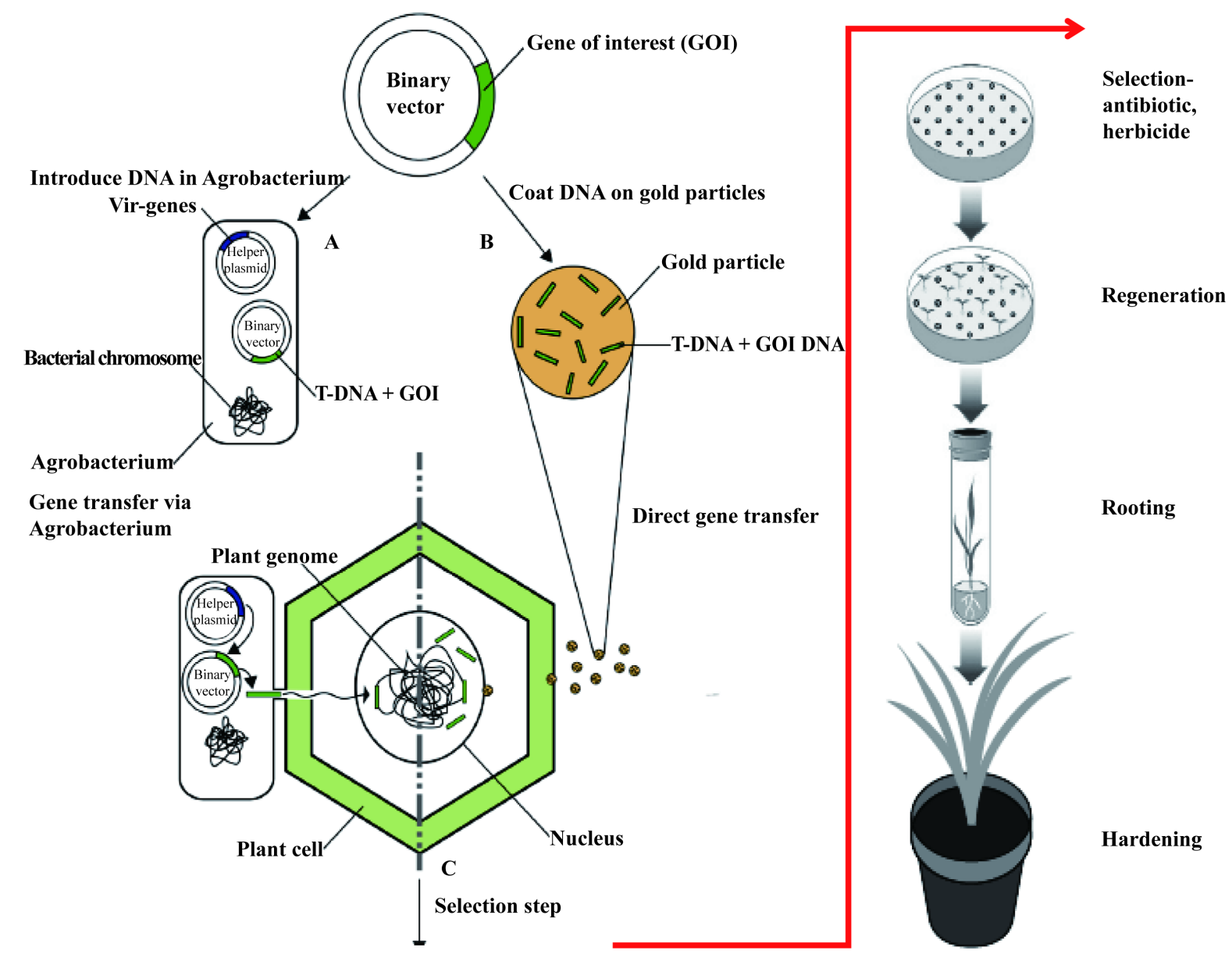

Figure 1. Schematic representation of physical and biological methods commonly used for gene transfer to plants and the general steps leading to the growth of a putative transgenic. (A) Agrobacterium-mediated T-DNA transfer. (B) Direct DNA transfer through particle bombardment or biolistics. (C) Regeneration and selection of transformed callus and shoots, adopted from [1] [5]. 


\section{Biological Method}

\section{Agrobacterium-Mediated Gene Transfer}

Agrobacterium tumefaciens is a Gram-negative soil phytopathogenic bacterium which causes crown gall disease in plants and it can be grown in vitro in simple culture media without any added plant growth hormones and the bacterium [9]. This disease is established by neoplastic growth caused by the integration of the transferred DNA (T-DNA) obtained from specific DNA fragments (Ti) plasmid into the plant nuclear genome [10]. This feature is widely used in plant biotechnology, and Agrobacterium is the most important tool employed to produce transgenic plants [5]. In the past three decades, the biology of Agrobacterium and its relations with host plant have been the subject of many studies, for recent review see [11].

The understanding of the T-DNA integration pathways have considerably enriched by releasing new studies and in the same time, it exposed many host factors that participate in these events [7] [11]. T-DNA integration for Agrobacterium includes two main steps: firstly, the T-strand is converted to a double-stranded form; and secondly, the host cell DNA repair machinery mediates the double-stranded T-DNA integration into double strand breaks in the host genome [11].

Briefly, the following steps of host genetic transformation facilitated by Agrobacterium are: The induction of Agrobacterium's virulence machinery results in expression and activation of the virulence genes (vir genes), some of these genes are important in the transfer of T-DNA from the bacterium to host cell, whereas others helps in targeting T-DNA to the nucleus and most likely to the precise integration site in the host cell for T-DNA [5] [12]. This first step mobilises a single stranded DNA segment from the (Ti) plasmid which usually contains one T-DNA region. However, in some cases, a Ti plasmid may comprise multiple T-DNA regions [13]. This section of transferred DNA (T-DNA), bounded by two (25) bp direct repeat sequences defined as right and left borders (RB and LB) [14], it is termed the T-strand, and the DNA present in between the border sequences is transferred to the receiver plant nucleus [11]. In addition, VirD2, linked with VirD1, forms a nuclease able to remove the T-strand by a strand-replacement mechanism, at the completion of which VirD2 remains covalently linked to the 5-end (RB) of the T-strand [14]. For more details, see Figure 2.

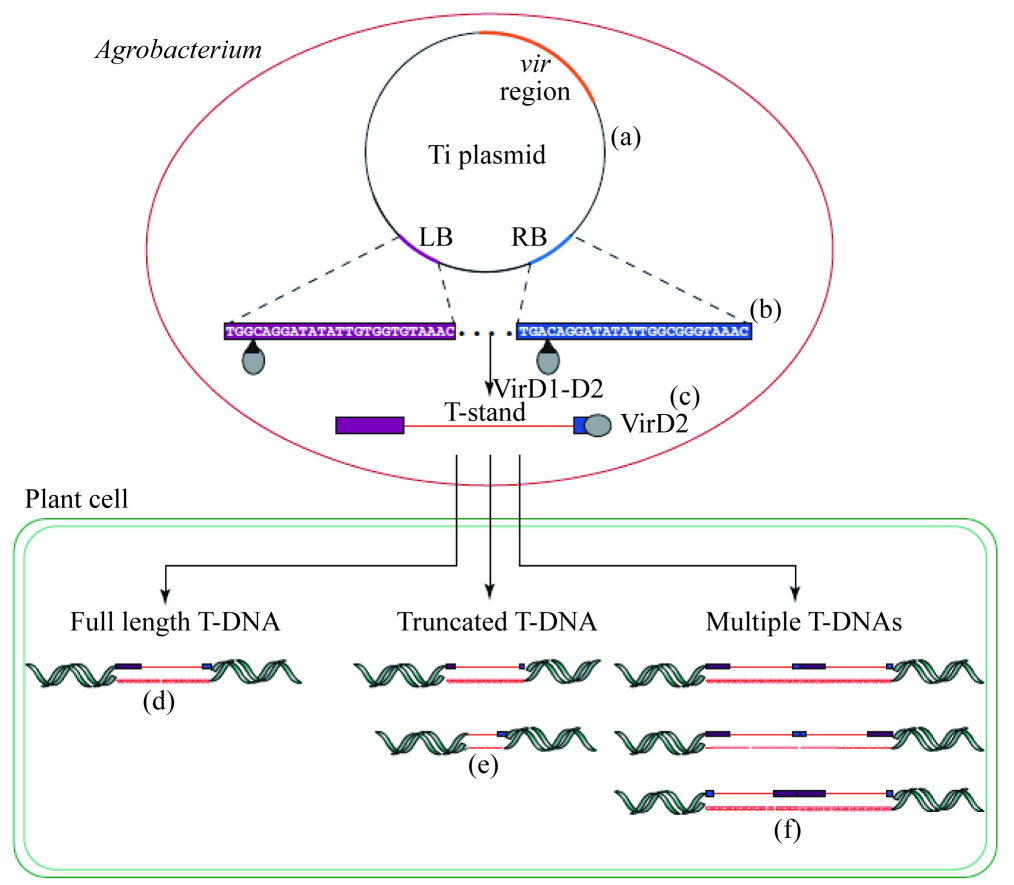

Figure 2. Structure representation of the Agrobacterium Ti-plasmid and integrated T-DNA molecules. (a) The T-DNA section includes left border (LB), right border (RB) and the virulence (vir) region. (b) The borders of T-DNA are 25-bp repeats and works as targets for the VirD1 - VirD2 endonuclease complex (c) As single-stranded DNA molecule, the (T-strand) is released and T-DNA typically take part into the host genome (d) In various orientationsas a single full-length or (e) truncated molecule in addition to (f) multiple molecules joined to each other [4]. 
This method has been found to be challenging due to the low copy number and large size of Ti plasmids, leading to difficulties in plasmid manipulation and isolation, and it limited in the range of plant species that can be transformed because not all tissues or species are susceptible to Agrobacterium [15] [16]. To support these limitations, it has been reported by the group of researchers in Japan and Australia Nakano, Suzuki [17], large DNA molecules about $100 \mathrm{~kb}$ integrated by this indirect method and tend to be rearranged with deletions, duplications and insertions not only in the transgenic rice lines but also in itself. Therefore, this method may not be the ideal for transformation large DNA fragments.

Beside some drawbacks for Agrobacterium transformation, this method still works in many labs and high transformation rate frequencies could be obtained. More recently, by group of researchers Chetty, Ceballos [18], four Agrobacterium tumefaciens strains (GV3101, EHA105, AGL1, and MP90) for the genetic transformation of tomato (Solanum lycopersicum L.) cultivar was evaluated. The reasons they chose Micro-Tom for their experiment was due to the fact that it differs from typical tomato cultivars by having two recessive genes, which confer the dwarf phenotype and it is preferred as a model system for functional genomics, because it shares several unique features with Arabidopsis, such as small size and short life cycle [19]. Transformation rate frequencies for all strains were $(65 \%, 40 \%, 35 \%$ and $15 \%)$ respectively. The analysis by comparative qPCR technique for duplex Taq-Man reactions showed that the strain MP90 was the most efficient in the transfer of single transgene insertions into the tomato genome regardless to their lowest transformation rate (see Table 1). Thus, their discovery could be used for functional genomics and biotechnological applications in tomato.

\section{Physical Methods}

\subsection{Microprojectile Bombardment}

Particle bombardment is a theoretically simple powerful tool for biotechnologists allowing direct gene transfer to a broad range of cells and tissues which have been found difficult to transform by other technique, and is more valuable for improving species which have high level of heterozygosity such as potato and cassava [20].

The term biolistic was established to describe the nature of the delivery of the foreign DNA into living cells, and the development of the particle bombardments from concept to useful process was first invented by Sanford [21], in which gene carriers can penetrate virtually any type of tissue or at least the first few cell layers and to generate transgenic plants in species which were not amenable to Agrobacterium-mediated genetic transformation.

Principally, the particle bombardment device comprises of a mechanism to accelerate the particles to desired speeds and adjust their penetration into the receiver cells. Initially, the gun powder discharge device was used to accelerate inert metal microprojectiles coated with biologically active compounds [21]. Soon after, this device was replaced with inert gas helium (Biolistics1 PDS-1000/He) to offer the force for microprojection [22]. The rupture disk assembly is the major part of this most commonly used device which controls the helium pressure and helium gas released by a rupture disc and partial vacuum to propel a macrocarrier plastic sheet loaded with DNA coated tungsten or gold. This disk assembly contains a gas acceleration tube with a rupture disk placed at the bottom of the tube inside a retaining cap. Subsequently, the gas chamber is evacuated and the helium gas pressure is allowed to build up to the desired level to break the rupture disk. Finally, at the optimized velocity

Table 1. Percentage of transgenic plants based on a duplexed TaqMan qPCR assay with 1,2 or 2 copies of nptII or uidA transgenes in their genomes, a total of 42 plants obtained with each Agrobacterium strain were used for the TaqMan assay [5].

\begin{tabular}{|c|c|c|c|c|c|c|}
\hline \multirow{3}{*}{ Agrobacterium Strain } & \multicolumn{6}{|c|}{ Transgene copy number (\%) } \\
\hline & \multicolumn{3}{|c|}{ nptII } & \multicolumn{3}{|c|}{ uidA } \\
\hline & 1 & 2 & $>2$ & 1 & 2 & $>2$ \\
\hline AGL1 & 52 & 24 & 24 & 52 & 29 & 19 \\
\hline EHA105 & 67 & 21 & 12 & 62 & 25 & 13 \\
\hline GV3101 & 52 & 33 & 15 & 55 & 31 & 14 \\
\hline MP90 & 76 & 24 & 0 & 67 & 33 & 0 \\
\hline
\end{tabular}


via metal screen, the optimized helium gas pressure forces the microprojectiles to deliver biologically active compounds and penetrate the target tissue to affect gene transfer [22] [23] (See Figure 3, for diagrammatic representation of this device). The main function of the microprojectiles is to create holes through which DNA passes into the cells. Therefore, a number of modifications have been made to the power source used to propel the microprojectiles to control microprojectile penetration into cells such as regulated nitrogen gas pressure, an air gun and compressed air [24]-[26]. A main difference in the air gun technique is that the DNA is suspended with the microprojectiles rather than being coated on them [25]. The creators of mentioned techniques assumed that the movement of DNA independent of microprojectiles which allows them to target small locations of tissues.

The critical factors to maximize transformation efficiency by this system are the delivery of optimal amount of DNA with minimal injury to the receiver plant tissue, size and density of microprojectiles, attachment of DNA to microprojectiles, helium pressure at which microprojectiles are propelled and distance between rupture disc are all important factors [4] [23]. Most of these parameters need to be optimized and differ with individual laboratories. By only changing the target diameter or adjusting the distance that the microparticles travel to the target tissue, transformation events may be affected [23].

One of the preferred methods for both transient gene expression studies and stable genetic transformation for improvement of crops is biolistic gene transfer [27]. For example, first transgenic sugarcane plants were generated by Bower and Birch [28], from embryonic callus, they easily recovered transgenic sugarcane plant with high DNA coated microprojectile by bombardment because the surface layer of sugarcane embryogenic callus obviously has a higher proportion of cells that are able to regenerate and proliferate that permit the selection of transformed plants [29]. Under the control of promoter Emu, transformation of a gene npt-II was delivered into sugarcane [30]. Subsequently, this transformation was confirmed by Southern hybridization.

More recently for biolistic transformation of sugarcane Xiong, Jung [31], by using linear expression cassettes three different DNA coating procedures were compared, namely; spermidine, protamine sulfate and the Seashell DNAdelTM Gold Carrier with patented precipitation buffer from Seashell Technology. The free base (Spermidine) lead to 2.65-fold and three-fold higher transient GUS expression than Seashell DNAdelTM and protamine,

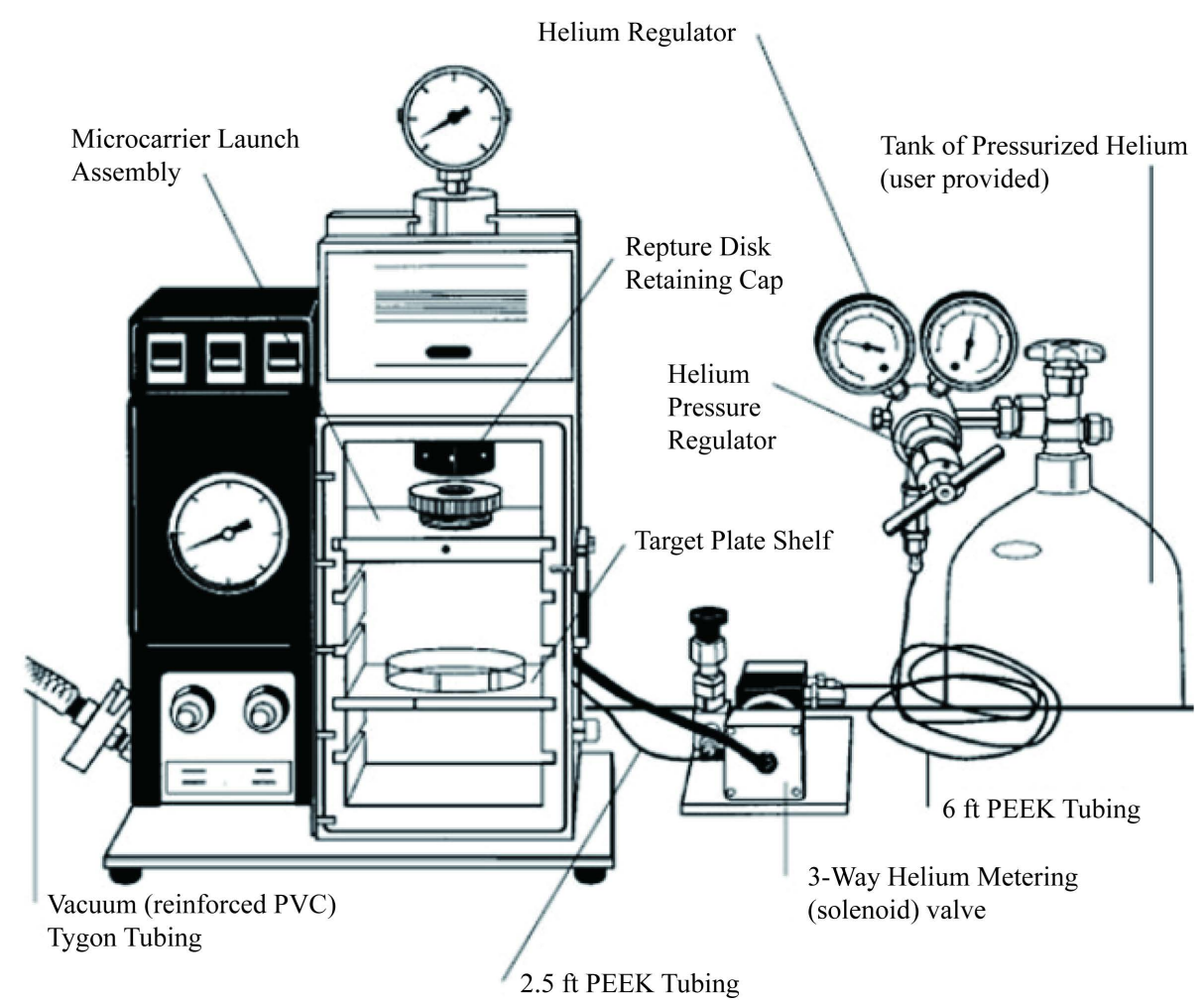

Figure 3. Diagrammatic representation of biolistic PDS-1000/He biolistic gun (courtesy biorad laboratories, USA) [1]. 
respectively and they assumed that all three DNA coating protocols are similarly effective for stable genetic transformation of sugarcane (For more details, see Table 2 and Figure 4).

Recently, progress of a new active transgenesis method based on particle bombardment would be more effective than common particle bombardment and integration of multiple copies of DNA could be decreased [32].

$\mathrm{Wu}, \mathrm{Du}$ [32] delivered DNA-enzyme complex into plant cells through the biolistic method by using $1 \mu \mathrm{m}$ gold microparticles. The codelivery of the DNA complex (DNA plasmid and protein) let to enhanced plant transformation efficiency. However; it required covalent modification of the protein so as to stay attached with the gold microparticle in the time of bombardment. Therefore, platform for codelivery the DNA complex to plant tissues by means of a biolistic particle delivery system will lead to advancements in plant genomic manipulation applications.

Delivery of biomolecules mediated by mesoporous silica nanoparticleis (MSNs) particularly interesting because without the assistance of protein transport systems, proteins are often unable to cross the barrier of cells membrane [33].

In general, the low activity of endocytosis and the barrier of cell walls limit the application of nanotechnology on plant systems. Up to now, only calcium phosphate nanoparticles and poly dendrimer (DNA vector),showed that particles could be entered into plants through simple co-culture methods and works as carriers for gene delivery without any additional assistance, and high transient delivery efficiency could be obtained [34]. However, this method was cost effective and should be developed further.

Table 2. Stable transformation efficiency for three coating treatments, same letters indicate lack of significant difference at $p$ $<0.05,\left(^{*}\right)$ For each bombardment $(20-30)$ calli were placed in the centre of the petri dish to cover a circular area of $4.6 \mathrm{~cm}^{2}$ [31].

\begin{tabular}{ccccc}
\hline Treatment & Experiment & $\begin{array}{c}\text { Number of } \\
\text { bombardments }\end{array}$ & $\begin{array}{c}\text { Number of } \\
\text { transgenic plants }\end{array}$ & $\begin{array}{c}\text { Number of transgenic } \\
\text { plants/bombardment }\end{array}$ \\
\hline Spermidine & I & 8 & 13 & 1.63 \\
II & III & 14 & 15 & 1.88 \\
Spermidine total & & 30 & 25 & $1.79 \pm 0.07$ \\
Protamine & I & 8 & 53 & 2.88 \\
II & 8 & 23 & 1.13 \\
Protamine total & III & 14 & 9 & 1.14 \\
Seashell DNA del TM & & 30 & 45 & $1.71 \pm 0.58$ \\
& I & 8 & 7 & 0.88 \\
\hline
\end{tabular}

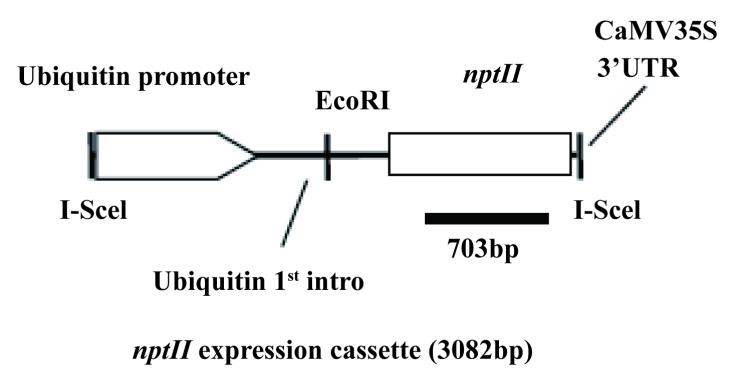

Figure 4. Schematic representation of the nptII expression cassette for stable transformation analysis. The black line underneath nptII gene represents the nptII ORF region (703 bps) that was used as probe in southern blot hybridization [31]. 
More recently, to develop plant transient gene expression system, Mou, Chang [35] used functionalized mesoporous silica nanoparticles. In this approach, MSNs worked as a cargo for deliver foreign DNA into Arabidopsis thaliana roots without any need for mechanical forces. In addition, gene expression was detected in the epidermal layer and in the more inner cortical and endodermal root tissues by both antibody labelling and fluorescence. This in particular is an advantage to the common particle bombardment technique which hardly delivers DNA into deeper plant tissues [35] (For more details, see Figure 5 and Figure 6).

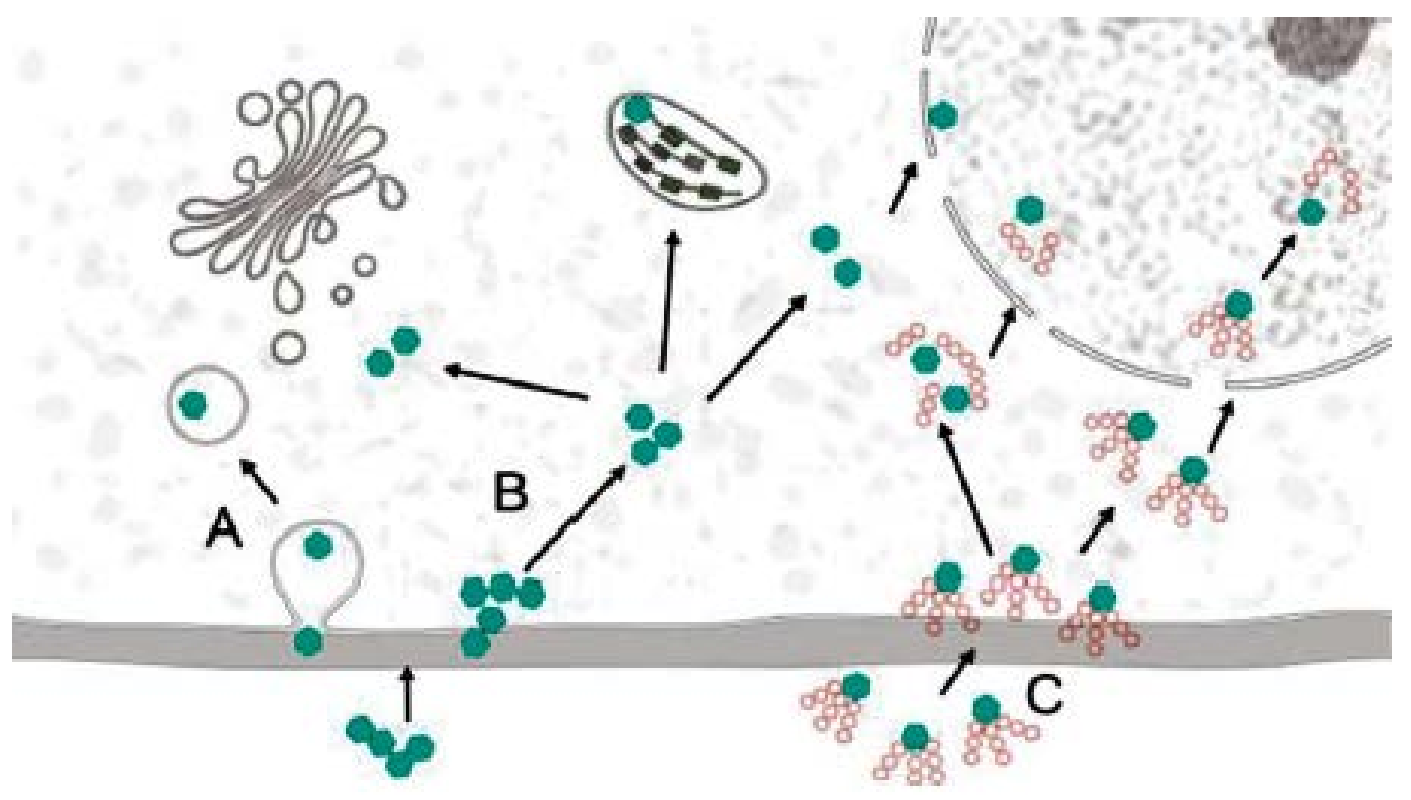

Figure 5. Possible routes of TMAPS/F-MSNs plasmid after internalization into the Arabidopsis root cell. Once passed through the cell wall, TMAPS/F-MSNs may be internalized by endocytosis (scheme A) or penetrate the plasma membrane (scheme B), which may be a primary route. Particles could enter organelles or stay in the cytoplasm after TMAPS/F-MSNs pass the plasma membrane such as plastids and the nucleus. The DNA-loaded TMAPS/F-MSN complex internalized into the plant cell (scheme C) could then reach the nucleus. MSNs and plasmid DNA may pass through the nuclear pore as a complex or DNA molecules may be released from the MSNs and enter the nucleus [3].

(a)

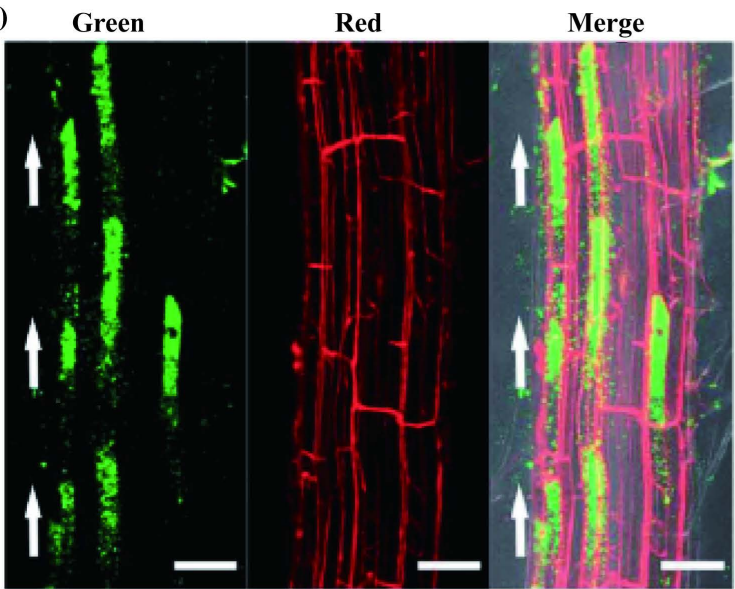

(b)

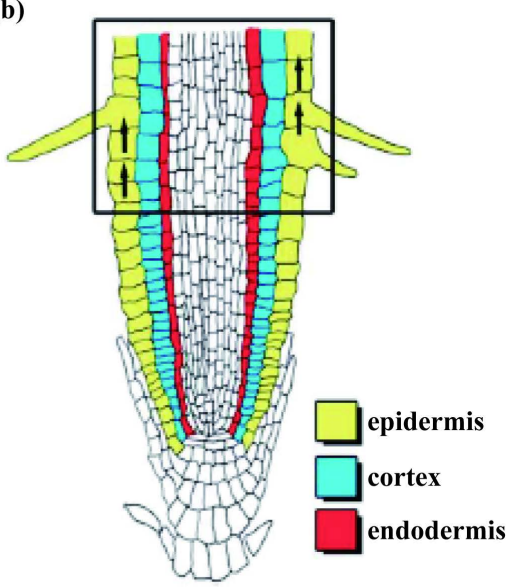

Figure 6. Polar distribution of internalized MSNs in Arabidopsis root cells. (a) Confocal images of uneven distribution of TMAPS/F-MSNs (green) in individual cells (arrows) after incubation for $24 \mathrm{~h}$ at $24 \mathrm{c}^{0}$ in $1 / 2$ MS. To label the cell walls and reveal cell viability, Arabidopsis roots were stained with PI (red). Scale bars: $50 \mathrm{~mm}$. (b) a schematic illustration of the Arabidopsis root. And then in the maturation zone of the root (black box), the TMAPS/F-MSNs was detected [3]. 


\subsection{Silicon Carbide-Mediated Transformation}

The use of silicon-mediated transformation first reported by Kaeppler, Somers [36] which is one of the least complicated techniques. In this technique, small needle-type silicon carbide whiskers with very high tensile strength are mixed with the gene of interest and plant cells, and the mixture is vortexed and then plated on culture medium [36]. Subsequently, the cultured cells will be assessed for DNA integration and insertion into the recipient cells. In this process, the created holes permit the DNA to be delivered into plant cells [37]. Stably transformed plant cells have been produced by using this kind of DNA delivery method [36] [38]. In addition, by exposing cells to high molarity of sorbitol, the efficiency of DNA delivery by silicon carbide whiskers could be increased [39].

Although the attributes of this method have been recognized for being simple, less resource requiring for DNA delivery into plants cells and cost effective [37] [38], it has also been reported that it imposes health hazards due to fiber inhalation and may be harmful to human beings, if not performed properly [40]. Therefore, there has been a search for other possible alternative, which could be used for similar DNA transfer purposes, as a consequence; the use of aluminum borate whiskers (ABW) was appeared [41]. The same group researchers improved this method by using multidirectional shaker instead of ordinary vortex. Recently, an efficient transgenic kabocha squash plants (Cucurbita moschata) have also been produced which was about (2.7\%) by penetrating cotyledonary node explants with (ABW) prior to inoculation with Agrobacterium [42].

Moreover, by group of researchers in Pakistan [43], the newly inexpensive and efficient protocol was developed for salt tolerance in cotton due to transgene overexpression of Arabidopsis vacuolar pyrophosphatase (AVP1) genes by using a silicon carbide whisker-mediated gene transfer system. In addition, from just $(1 \mathrm{~g})$ embryogenic cotton calli treated with whiskers, they generated about 60 fertile plants of 20 independent transgenic events. Furthermore, for optimum efficiency of cotton embryogenic callus, transformations of cotton calli were evaluated giving about (94\%).

\subsection{Electroporation-Mediated Transformation}

The application of electroporation has a major impact on genetic manipulation of organism. In this method, the foreign DNA migrates through high voltage resulting in formation of pores in the plasma membrane [44]. In general, this method was originally developed for protoplast transformation but has subsequently been revealed to work with whole plant cells [45] [46].

Practically, high electric fields are applied to protoplasts or cells suspended in a liquid culture medium enclosed in a discharge chamber [47]. Then, by a capacitor discharge, the electric field is applied which in some commercial instruments can provide high voltage, up to (3000) [48]. The voltage and time applied relies on the cell type used for electroporation. In addition, efficiency of electroporation may be affected by surface concentration of DNA and tolerance of cells to membrane permeation [49] [50].

However, there was an attention in bypassing the protoplasts for electroporation because the regeneration of fertile transgenic plants system has not been developed in most plant species [49]. In addition, the main physical barrier to electroporation maybe is the thickness of recipient cell walls [8].

The first stable transformation through this method was with rice seeds cultured (2) days prior which has been subjected by electro-injection with a plasmid having neomycin phosphotransferase II (NPTII) gene and then transgenic rice were regenerated through somatic embryogenesis [51]. Subsequently, by using the pulse-discharging electroporation system, stable transformants has been produced for immature corn embryos [52].

\section{Application of Disease Resistance in Crops}

\subsection{Agrobacterium-Mediated Gene Transfer}

Recently, resistance against Leaf Spot under improved form of CaMV 35S promoter by over expressing rice chitinase-3 gene in transgenic peanut through Agrobacterium mediated gene transfer was found [53]. Agrobacterium tumefaciens strain LB4404 was used holding the binary vector (pB1333-EN4-RCG3) comprising the hygromycin resistance (hpt) and chitinase gene as selectable marker (see Figure 7). In addition, through Southern hybridization analysis of the genomic DNA, the integration of transgene in the nuclear genome of the putative transformed plants was confirmed.

More than $60 \%$ of regenerated plantlets were observed whereas transgenic healthy plants with over $42 \%$ 
transformation frequency were formed and all plants were normally grown. Subsequently, by infection with the microspores, (T1) plants were tested for resistance against Leaf Spot. Transgenic strains showed a higher resistance than the non-transgenic plants. Their results indicated that the lines with high enzyme activity similarly showed a high resistance against leaf spot (see Table 3).

\subsection{Microprojectile Bombardment}

Tissue culture and transformation were the most difficult task for developing the transgenic papaya [54]. However, this mission was taken into consideration by Fitch and Manshardt [55], three different cultivars (Sunset, Sunrise Kapoho) were targeted. To develop a papaya regeneration system through organogenesis, a great effort has been made by Fitch but unfortunately he was unsuccessful. Soon after, a quick decision has been made to use embryogenic tissue transformation through particle bombardments. Therefore, with tungsten particles coated with DNA of the PRSV HA 5-1 coat protein gene with the gene gun, embryogenic tissue was bombarded [56]. Then after 15 months in the greenhouse, transgenic plants were obtained and growing in the good conditions [57].

However, genetic engineering through particle bombardment and Agrobacterium-mediate both create relatively random integration of the transgene into the host genome [58]. In addition, the expression of the transgenes considerably affected by the random integration and similarly gene disruption could possibly occur due to this integration [58]. Southern blot hybridization, however, is useful mechanism for evaluating transgene copy number of insertion but the physical location of the transgene insertion cannot be indicated [58].

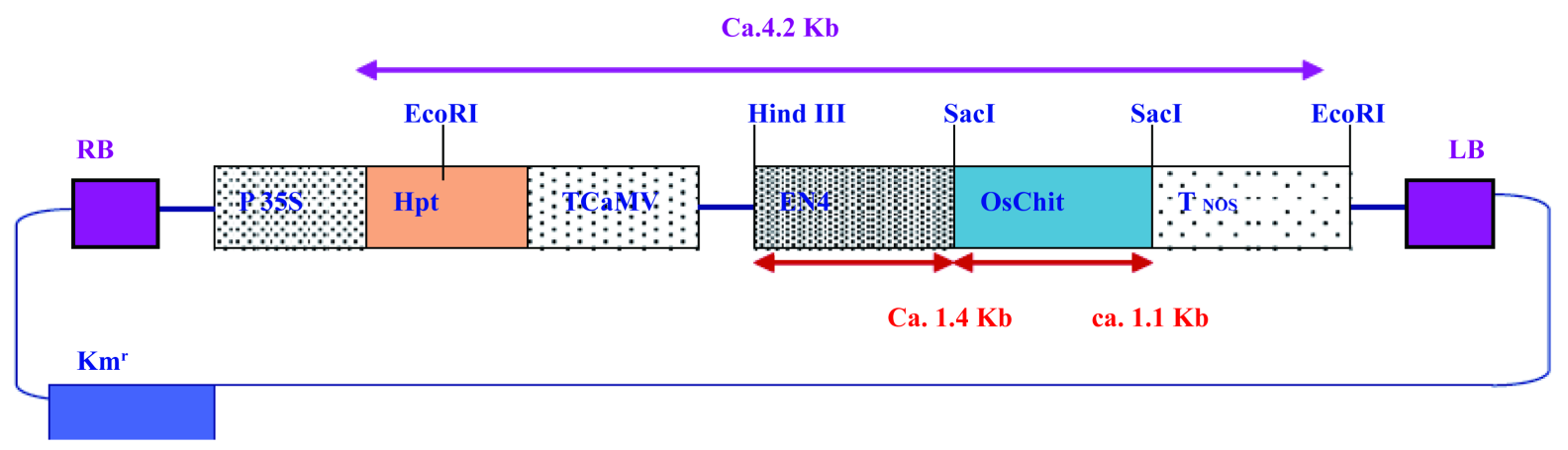

Figure 7. Vector pB1333-EN4-RCG3 [2].

Table 3. Rice chitinase activity and pathogen resistance assay in peanut. In response to the hydrogen peroxide, Oschit transcripts accumulate. Therefore, an Oschit band with the expected size of (750-bp) has been amplified from transgenic lines [35].

\begin{tabular}{|c|c|c|c|c|c|}
\hline Transgenic line & $\begin{array}{l}\text { RT-PCR } \\
\text { result }\end{array}$ & $\begin{array}{l}\text { Oschit } \\
\text { activity }\end{array}$ & $\begin{array}{c}\text { Enhanced chitinase } \\
\text { activity }\end{array}$ & $\begin{array}{l}\text { Resistance to } \\
\text { C. arachidicola }\end{array}$ & $\begin{array}{c}\text { Correlation to } \\
\text { hypothesis }\end{array}$ \\
\hline Golden untransformed & - & 1 & - & - & - \\
\hline 09-G1 & + & 6.5 & $\mathrm{Y}$ & $\mathrm{Y}$ & $\sqrt{ }$ \\
\hline 09-G2 & + & 3.5 & $\mathrm{Y}$ & $\mathrm{Y}$ & $\sqrt{ }$ \\
\hline 09-G7 & + & 6.2 & $\mathrm{Y}$ & $\mathrm{Y}$ & $\sqrt{ }$ \\
\hline 09-G7.3 & + & 3.2 & $\mathrm{Y}$ & $\mathrm{N}$ & $x$ \\
\hline 09-G9 & + & 1.9 & $\mathrm{~N}$ & $\mathrm{~N}$ & $\sqrt{ }$ \\
\hline 09-B4 & + & 2.1 & $\mathrm{~N}$ & $\mathrm{Y}$ & $x$ \\
\hline 09-B5.4 & + & 6 & $\mathrm{Y}$ & $\mathrm{Y}$ & $\sqrt{ }$ \\
\hline 09-B13 & + & 2.3 & $\mathrm{Y}$ & $\mathrm{N}$ & $x$ \\
\hline 10-B2 & + & 1.8 & $\mathrm{~N}$ & $\mathrm{~N}$ & $\sqrt{ }$ \\
\hline 10-B3.4 & + & 3 & $\mathrm{Y}$ & $\mathrm{N}$ & $x$ \\
\hline
\end{tabular}


Researchers were thinking about more attractive technique to control disease resistance for papaya. Therefore, genetic resistance within the species may be more explained with the advantage of fully first sequenced genome of transgenic papaya [59]. Recently from a wild relative by back crossing, the introgression of papaya ringspot virus (PRSV) resistance was successfully accomplished [60]. This provides new hope that other wild relative traits may be introgressed into papaya in the near future.

\section{Conclusions}

Development of gene transfer systems in plants probably one of the most challenging aspects of plant research. Now day, the two methods of choice are definitely the Agrobacterium-mediated and the biolistic-mediated DNA delivery systems. From two decades ago, development of transformation technology was viewed primarily as an objective to the production of transgenic crops with improved agronomic characteristics for enhanced crop productivity [6]. However, the emergence of functional genomics and the requirement for high-throughput technology for assessment of gene function in plants have generated a whole new focus on generation of transgenic plants [61]. This circumstance has become even more evident for economically important crop plants, in which high efficiency transformation systems are generally missing, compared to model systems such as Arabidopsis thaliana [62]. However, progress made in rice and corn is encouraging with the use of Agrobacterium for transformation in a fairly high-throughput manner [63] [64]. The focus is, therefore, still focused around those other economically important plants, which can be made amenable for high-throughput gene transfer in order to make greatest use of the huge repertoire of data flowing from genome projects.

Therefore, gene transfer methods to plants will continue to receive renewed interest in the future. The development of nanoparticles for DNA delivery into plant cells is emerging [65] and there are possibilities to combine the benefits of biolistic and Agrobacterium in the near future [66]. Meanwhile, the approach of in plant transformation using Agrobacterium is likely to continue getting attention, due to avoidance of a tissue culture step for the regeneration of transformation events. Finally, the likely achievements will come from a combination of several existing methods, with the most suitable, and most likely popular, gene transfer method having the accessibility, and simplicity for a large number of plant species.

\section{Acknowledgements}

It is a great pleasure that we can take this opportunity to send thanks and appreciation to Dr. Nawroz Abdul Razzak who were available every times and supported us by providing valuable advices. We would also like to point out the contributing role that the University of Sulaimani has played in establishing and growing the knowledge of all lecturers and supported us all of the times. Finally, we would like to express our gratitude for the sacrifices of Peshmarga and their bravery in the fight against IS.

\section{References}

[1] Kole, C. (2010) Transgenic Crop Plants: Volume 1: Principles and Development. Springer.

[2] Larkin, P.J. and Scowcroft, W. (1981) Somaclonal Variation-A Novel Source of Variability from Cell Cultures for Plant Improvement. Theoretical and Applied Genetics, 60, 197-214. http://dx.doi.org/10.1007/BF02342540

[3] Budar, F., et al. (1986) Agrobacterium-Mediated Gene Transfer Results Mainly in Transgenic Plants Transmitting T-DNA as a Single Mendelian Factor. Genetics, 114, 303-313.

[4] Bhojwani, S.S. and Dantu, P.K. (2013) Plant Tissue Culture: An Introductory Text. Springer, London. http://dx.doi.org/10.1007/978-81-322-1026-9

[5] Anami, S., et al. (2013) Higher Plant Transformation: Principles and Molecular Tools. The International Journal of Developmental Biology, 57, 483-494. http://dx.doi.org/10.1387/ijdb.130232mv

[6] Davey, M.R., et al. (2010) Generation and Deployment of Transgenic Crop Plants: An Overview, in Transgenic Crop Plants. Springer, 1-29. http://dx.doi.org/10.1007/978-3-642-04809-8_1

[7] Meyers, B., et al. (2010) Nuclear and Plastid Genetic Engineering of Plants: Comparison of Opportunities and Challenges. Biotechnology Advances, 28, 747-756. http://dx.doi.org/10.1016/j.biotechadv.2010.05.022

[8] Barampuram, S. and Zhang, Z.J. (2011) Recent Advances in Plant Transformation, in Plant Chromosome Engineering. Springer, 1-35. http://dx.doi.org/10.1007/978-1-61737-957-4 1

[9] Braun, A.C. and Laskaris, T. (1942) Tumor Formation by Attenuated Crown-Gall Bacteria in the Presence of 
Growth-Promoting Substances. Proceedings of the National Academy of Sciences of the United States of America, 28, 468. http://dx.doi.org/10.1073/pnas.28.11.468

[10] Fraley, R.T., et al. (1985) The SEV System: A New Disarmed Ti Plasmid Vector System for Plant Transformation. Nature Biotechnology, 3, 629-635. http://dx.doi.org/10.1038/nbt0785-629

[11] Tzfira, T., et al. (2004) Agrobacterium T-DNA Integration: Molecules and Models. Trends in Genetics, 20, $375-383$. http://dx.doi.org/10.1016/j.tig.2004.06.004

[12] Stachel, S.E. and Nester, E.W. (1986) The Genetic and Transcriptional Organization of the Vir Region of the A6 Ti Plasmid of Agrobacterium tumefaciens. The EMBO Journal, 5, 1445-1454.

[13] Merlo, D.J., Nutter, R.C., Montoya, A.L., et al. (1980) The Boundaries and Copy Numbers of Ti Plasmid T-DNA Vary in Crown Gall Tumors. Molecular and General Genetics MGG, 177, 637-643. http://dx.doi.org/10.1007/bf00272674

[14] Gelvin, S.B. (2000) Agrobacterium and Plant Genes Involved in T-DNA Transfer and Integration. Annual Review of Plant Biology, 51, 223-256. http://dx.doi.org/10.1146/annurev.arplant.51.1.223

[15] Sone, T., Nagamori, E., Ikeuchi, T., et al. (2002) A Novel Gene Delivery System in Plants with Calcium Alginate Micro-Beads. Journal of Bioscience and Bioengineering, 94, 87-91. http://dx.doi.org/10.1016/S1389-1723(02)80123-2

[16] Wada, N., et al. (2011) A Novel Gene Delivery System in Plants with Calcium Alginate Micro-Beads. In: Stewart, C.N., et al., Eds., Plant Transformation Technologies, Wiley-Blackwell, Oxford, 73-82.

[17] Nakano, A., Suzuki, G., Yamamoto, M., et al. (2005) Rearrangements of Large-Insert T-DNAs in Transgenic Rice. Molecular Genetics and Genomics, 273, 123-129. http://dx.doi.org/10.1007/s00438-005-1116-y

[18] Chetty, V.J., Ceballos, N., Garcia, D., et al. (2013) Evaluation of Four Agrobacterium tumefaciens Strains for the Genetic Transformation of Tomato (Solanum lycopersicum L.) Cultivar Micro-Tom. Plant Cell Reports, 32, $239-247$. http://dx.doi.org/10.1007/s00299-012-1358-1

[19] Dan, Y.H., Yan, H., Munyikwa, T., et al. (2006) MicroTom-A High-Throughput Model Transformation System for Functional Genomics. Plant Cell Reports, 25, 432-441. http://dx.doi.org/10.1007/s00299-005-0084-3

[20] Gardner, R.C. (1993) Gene Transfer into Tropical and Subtropical Crops. Scientia Horticulturae, 55, 65-82. http://dx.doi.org/10.1016/0304-4238(93)90025-L

[21] Sanford, J.C. (1988) The Biolistic Process. Trends in Biotechnology, 6, 299-302. http://dx.doi.org/10.1016/0167-7799(88)90023-6

[22] Kikkert, J.R. (1993) The Biolistic ${ }^{\circledR}$ PDS-1000/He Device. Plant Cell, Tissue and Organ Culture, 33, $221-226$. http://dx.doi.org/10.1007/BF02319005

[23] Klein, T.M., et al. (2011) Particle Bombardment: An Established Weapon in the Arsenal of Plant Biotechnologists. In: Stewart, C.N., et al., Eds., Plant Transformation Technologies, Wiley-Blackwell, Oxford.

[24] Morikawa, H., Iida, A. and Yamada, Y. (1989) Transient Expression of Foreign Genes in Plant Cells and Tissues Obtained by a Simple Biolistic Device (Particle-Gun). Applied Microbiology and Biotechnology, 31, 320-322. http://dx.doi.org/10.1007/BF00258417

[25] Oard, J.H., Paige, D.F., Simmonds, J.A. and Gradziel, T.M. (1990) Transient Gene Expression in Maize, Rice, and Wheat Cells Using an Airgun Apparatus. Plant Physiology, 92, 334-339. http://dx.doi.org/10.1104/pp.92.2.334

[26] Iida, A., Seki, M., Kamada, M., et al. (1990) Gene Delivery into Cultured Plant Cells by DNA-Coated Gold Particles Accelerated by a Pneumatic Particle Gun. Theoretical and Applied Genetics, 80, 813-816. http://dx.doi.org/10.1007/BF00224198

[27] Taylor, N.J. and Fauquet, C.M. (2002) Microparticle Bombardment as a Tool in Plant Science and Agricultural Biotechnology. DNA and Cell Biology, 21, 963-977. http://dx.doi.org/10.1089/104454902762053891

[28] Bower, R. and Birch, R.G. (1992) Transgenic Sugarcane Plants via Microprojectile Bombardment. The Plant Journal, 2, 409-416. http://dx.doi.org/10.1111/j.1365-313X.1992.00409.x

[29] Raghuwanshi, A. and Birch, R.G. (2010) Genetic Transformation of Sweet Sorghum. Plant Cell Reports, 29, $997-1005$. http://dx.doi.org/10.1007/s00299-010-0885-X

[30] Birch, R. and Maretzki, A. (1993) Transformation of Sugarcane. In: Bajaj, Y.P.S., Ed., Plant Protoplasts and Genetic Engineering IV, Springer, Berlin, 348-360.

[31] Xiong, Y., Jung, J.H., Zeng, Q.C., et al. (2013) Comparison of Procedures for DNA Coating of Micro-Carriers in the Transient and Stable Biolistic Transformation of Sugarcane. Plant Cell, Tissue and Organ Culture (PCTOC), 112, 95-99. http://dx.doi.org/10.1007/s11240-012-0208-8

[32] Wu, J., Du, H.W., Liao, X.W., et al. (2011) An Improved Particle Bombardment for the Generation of Transgenic Plants by Direct Immobilization of Relleasable Tn5 Transposases onto Gold Particles. Plant Molecular Biology, 77, 117-127. http://dx.doi.org/10.1007/s11103-011-9798-5 
[33] Wu, P.P., Bai, P., Lei, Z.B., et al. (2011) Gold Nanoparticles Supported on Functionalized Mesoporous Silica for Selective Oxidation of Cyclohexane. Microporous and Mesoporous Materials, 141, 222-230. http://dx.doi.org/10.1016/j.micromeso.2010.11.011

[34] Naqvi, S., Maitra, A.N., Abdin, M.Z., et al. (2012) Calcium Phosphate Nanoparticle Mediated Genetic Transformation in Plants. Journal of Materials Chemistry, 22, 3500-3507. http://dx.doi.org/10.1039/c2jm11739h

[35] Mou, C.-Y., et al. (2013) A Simple Plant Gene Delivery System Using Mesoporous Silica Nanoparticles as a Carrier. Journal of Materials Chemistry B, 1, 5279.

[36] Kaeppler, H.F., Somers, D.A., Rines, H.W. and Cockburn, A.F. (1992) Silicon Carbide Fiber-Mediated Stable Transformation of Plant Cells. Theoretical and Applied Genetics, 84, 560-566. http://dx.doi.org/10.1007/bf00224152

[37] Songstad, D.D., Somers, D.A. and Griesbach, R.J. (1995) Advances in Alternative DNA Delivery Techniques. Plant Cell, Tissue and Organ Culture, 40, 1-15. http://dx.doi.org/10.1007/BF00041112

[38] Wang, K., Drayton, P., Frame, B., et al. (1995) Whisker-Mediated Plant Transformation: An Alternative Technology. In Vitro Cellular \& Developmental Biology-Plant, 31, 101-104. http://dx.doi.org/10.1007/BF02632245

[39] Wang, J.H., Wieser, H., Pawelzik, E., et al. (2005) Impact of the Fungal Protease Produced by Fusarium culmorum on the Protein Quality and Breadmaking Properties of Winter Wheat. European Food Research and Technology, 220, 552-559. http://dx.doi.org/10.1007/s00217-004-1112-1

[40] Svensson, I., Artursson, E., Leanderson, P., et al. (1997) Toxicity in Vitro of Some Silicon Carbides and Silicon Nitrides: Whiskers and Powders. American Journal of Industrial Medicine, 31, 335-343. http://dx.doi.org/10.1002/(SICI)1097-0274(199703)31:3<335::AID-AJIM10>3.0.CO;2-1

[41] Mizuno, K., Takahashi, W., Ohyama, T., et al. (2004) Improvement of the Aluminum Borate Whisker-Mediated Method of DNA Delivery into Rice Callus. Plant Production Science, 7, 45-49. http://dx.doi.org/10.1626/pps.7.45

[42] Nanasato, Y., Konagaya, K.-I., Okuzaki, A., et al. (2011) Agrobacterium-Mediated Transformation of Kabocha Squash (Cucurbita moschata Duch) Induced by Wounding with Aluminum Borate Whiskers. Plant Cell Reports, 30, 14551464. http://dx.doi.org/10.1007/s00299-011-1054-6

[43] Asad, S., Mukhtar, Z., Nazir, F., et al. (2008) Silicon Carbide Whisker-Mediated Embryogenic Callus Transformation of Cotton (Gossypium hirsutum L.) and Regeneration of Salt Tolerant Plants. Molecular Biotechnology, 40, 161-169. http://dx.doi.org/10.1007/s12033-008-9072-5

[44] Hiromichi, M., Asako, I., Chiaki, M., et al. (1986) Gene Transfer into Intact Plant Cells by Electroinjection through Cell Walls and Membranes. Gene, 41, 121-124. http://dx.doi.org/10.1016/0378-1119(86)90274-X

[45] Neumann, E. and Rosenheck, K. (1972) Permeability Changes Induced by Electric Impulses in Vesicular Membranes. The Journal of Membrane Biology, 10, 279-290. http://dx.doi.org/10.1007/BF01867861

[46] Fromm, M., Taylor, L.P. and Walbot, V. (1985) Expression of Genes Transferred into Monocot and Dicot Plant Cells by Electroporation. Proceedings of the National Academy of Sciences of the United States of America, 82, 5824-5828. http://dx.doi.org/10.1073/pnas.82.17.5824

[47] Mischke, S., Saunders, J.A. and Owens, L. (1986) A Versatile Low-Cost Apparatus for Cell Electrofusion and Other Electrophysiological Treatments. Journal of Biochemical and Biophysical Methods, 13, 65-75. http://dx.doi.org/10.1016/0165-022X(86)90018-7

[48] BIO-RAD (2013) Gene Pulser Xcell ${ }^{\mathrm{TM}}$ Electroporation Systems. http://www.bio-rad.com/en-us/product/gene-pulser-xcell-electroporation-systems?WT.srch=1\&WT.mc_id=aw-gxd-euelectroporation\&WT.knsh_id=779cdfd1-7c5a-68e8-ca52-0000241ad3bd\&gclid=CPbky6CYzroCFdPItAodQHAAxg

[49] Saunders, J.A., Matthews, B.F. and Miller, P.D. (1989) Plant Gene Transfer Using Electrofusion and Electroporation. In: Neumann, E., Sowers, A.E. and Jordan, C.A., Eds., Electroporation and Electrofusion in Cell Biology, Plenum Press, New York, 343-354. http://dx.doi.org/10.1007/978-1-4899-2528-2_22

[50] Fisk, H.J. and Dandekar, A.M. (2004) Electroporation: Introduction and Expression of Transgenes in Plant Protoplasts. In: Dunwell, J.M. and Wetten, A.C., Eds., Transgenic Plants: Methods and Protocols, Springer, New York, 79-90. http://dx.doi.org/10.1385/1-59259-827-7:079

[51] Xu, X., Shi, H. and Li, B. (1995) Transgenic Indica Rice Plants by Electroporation of Seed Embryo Cells. In: Potrykus, I. and Spangenberg, G., Eds., Gene Transfer to Plants, Springer, Berlin Heidelberg, 201-207. http://dx.doi.org/10.1007/978-3-642-79247-2_24

[52] Ke, X.Y., Zhang, X.W., Shi, H.P. and Li, B.J. (1996) Electroporation of Immature Maize Zygotic Embryos and Regeneration of Transgenic Plants. Transgenic Research, 5, 219-221. http://dx.doi.org/10.1007/BF01969713

[53] Iqbal, M.M., Nazir, F., Ali, S., et al. (2012) Over Expression of Rice Chitinase Gene in Transgenic Peanut (Arachis hypogaea L.) Improves Resistance against Leaf Spot. Molecular Biotechnology, 50, 129-136. http://dx.doi.org/10.1007/s12033-011-9426-2 
[54] Ming, R.M. and Paul, H. (2013) Genetics and Genomics of Papaya. Springer, New York.

[55] Fitch, M.M. and Manshardt, R.M. (1990) Somatic Embryogenesis and Plant Regeneration from Immature Zygotic Embryos of Papaya (Carica papaya L.). Plant Cell Reports, 9, 320-324. http://dx.doi.org/10.1007/BF00232860

[56] Fitch, M.M., Manshardt, R.M., Gonsalves, D., et al. (1990) Stable Transformation of Papaya via Microprojectile Bombardment. Plant Cell Reports, 9, 189-194. http://dx.doi.org/10.1007/BF00232177

[57] Fitch, M.M., Manshardt, R.M., Gonsalves, D., et al. (1992) Virus Resistant Papaya Plants Derived from Tissues Bombarded with the Coat Protein Gene of Papaya Ringspot Virus. Bio/Technology, 10, 1466-1472. http://dx.doi.org/10.1038/nbt1192-1466

[58] VanBuren, R. and Ming, R. (2014) Sequencing and Assembly of the Transgenic Papaya Genome. In: Ming, R. and Moore, P.H., Eds., Genetics and Genomics of Papaya, Springer, New York, 187-203. http://dx.doi.org/10.1007/978-1-4614-8087-7_11

[59] Ming, R., Hou, S.B., Feng, Y., et al. (2008) The Draft Genome of the Transgenic Tropical Fruit Tree Papaya (Carica papaya Linnaeus). Nature, 452, 991-996. http://dx.doi.org/10.1038/nature06856

[60] Siar, S.V., Beligan, G.A., Sajise, A.J.C., et al. (2011) Papaya Ringspot Virus Resistance in Carica papaya via Introgression from Vasconcellea quercifolia. Euphytica, 181, 159-168. http://dx.doi.org/10.1007/s10681-011-0388-Z

[61] Li, J.R., Ye, X.G., An, B.Y., et al. (2012) Genetic Transformation of Wheat: Current Status and Future Prospects. Plant Biotechnology Reports, 6, 183-193. http://dx.doi.org/10.1007/s11816-011-0213-0

[62] Gelvin, S.B. (2010) Plant Proteins Involved in Agrobacterium-Mediated Genetic Transformation. Annual Review of Phytopathology, 48, 45-68. http://dx.doi.org/10.1146/annurev-phyto-080508-081852

[63] Ombori, O., Muoma, J.V.O. and Machuka, J. (2013) Agrobacterium-Mediated Genetic Transformation of Selected Tropical Inbred and Hybrid Maize (Zea mays L.) Lines. Plant Cell, Tissue and Organ Culture (PCTOC), 113, 11-23.

[64] Saika, H. and Toki, S. (2010) Mature Seed-Derived Callus of the Model Indica Rice Variety Kasalath Is Highly Competent in Agrobacterium-Mediated Transformation. Plant Cell Reports, 29, 1351-1364. http://dx.doi.org/10.1007/s00299-010-0921-X

[65] Hao, Y.Z., Yang, X.Y., Shi, Y.Z., et al. (2013) Magnetic Gold Nanoparticles as a Vehicle for Fluorescein Isothiocyanate and DNA Delivery into Plant Cells. Botany, 91, 457-466. http://dx.doi.org/10.1139/cjb-2012-0281

[66] Jackson, M.A., Anderson, D.J. and Birch, R.G. (2013) Comparison of Agrobacterium and Particle Bombardment Using Whole Plasmid or Minimal Cassette for Production of High-Expressing, Low-Copy Transgenic Plants. Transgenic Research, 22, 143-151. http://dx.doi.org/10.1007/s11248-012-9639-6 